\title{
$\beta$-Lactamase of Lysobacter enzymogenes: cloning, characterization and expression of the gene and comparison of the enzyme to other lactamases
}

\author{
Gregory J. Boras, Samson Au, Kenneth L. Roy and Richard G. von Tigerstrom* \\ Department of Microbiology, University of Alberta, Edmonton, Alberta T6G 2E9, Canada
}

(Received 17 September 1992; revised 4 January 1993; accepted 15 January 1993)

\begin{abstract}
The gene for the periplasmic $\beta$-lactamase of Lysobacter enzymogenes was isolated as part of a $1017 \mathrm{bp}$ EcoRI fragment and the nucleotide sequence of the gene was determined. It has a $G+C$ content of $71.5 \%$ and encodes a 27 amino acid signal sequence and the mature $\beta$-lactamase of 276 amino acids which has a mass of $29146 \mathrm{Da}$. The enzyme appears to be unique to $L$. enzymogenes but its amino acid sequence shows a high degree of homology with the amino acid sequences of the lactamase from Citrobacter diversus and other Class A $\beta$-lactamases. The $\beta$-lactamase gene of $L$. enzymogenes was expressed in Escherichia coli using pUC118 as the vector. The production of active $\beta$-lactamase was highest after the active growth phase of the expression host and reached levels which were about three times higher than those obtained with $L$. enzymogenes.
\end{abstract}

\section{Introduction}

Lysobacter enzymogenes produces a number of extracellular enzymes. Some are secreted into the medium and others are localized in the cell envelope. One of the cell-associated enzymes is an inducible, periplasmic $\beta$ lactamase (von Tigerstrom \& Boras, 1990). This enzyme was found to have a molecular mass of about $28 \mathrm{kDa}$ and a high isoelectric point, and its activity was inhibited by $p$-chloromercuribenzoate ( $p \mathrm{CMB}), p$-chloromercuribenzenesulphonic acid ( $p$ CMBS) and clavulanic acid. Based primarily on its substrate specificity, it was thought initially to belong to Group 2B, perhaps being similar in its properties to the $\beta$-lactamase of Pseudomonas cepacia (Bush, 1989).

A large number of chromosome- and plasmid-encoded $\beta$-lactamases have been reported from Gram-positive and Gram-negative bacteria and various schemes have been used to classify these enzymes (Ambler, 1980; Bush, 1989). They are produced by both pathogenic and non-

*Author for correspondence. Tel. (403) 492 3271; fax (403) 4922216.

Abbreviations: PADAC, 7-(thienyl-2-acetamido)-3-[4- $N, N$-dimethylaminophenylazo)-pyridinium methyl]-3-cephem-4-carboxylic acid; $p \mathrm{CMB}, p$-chloromercuribenzoate; $p$ CMBS, $p$-chloromercuribenzenesulphonic acid.

The nucleotide sequence data reported in this paper have been submitted to GenBank and assigned the accession number M97392. pathogenic organisms and have received more attention than most other groups of enzymes. One reason for this is their clinical importance, since they are often responsible for the resistance of bacteria to $\beta$-lactam antibiotics. In addition, the large amount of information which has been obtained about $\beta$-lactamases makes studies of the structure-function relationship and the molecular evolution of the enzymes possible. The classification scheme proposed by Ambler (1980) is based on the primary structures of $\beta$-lactamases. The amino acid sequences of more than $20 \beta$-lactamases which belong to Class A according to this scheme are now known, most having been deduced from the DNA sequence of their respective genes. They have been used in comparative studies (Forsman et al., 1990; Pastor et al., 1990; Boissinot \& Levesque, 1990; Huletsky et al., 1990; Ambler et al., 1991; Kirby, 1992) and, to standardize further comparisons, a consensus sequence has been proposed for enzymes of this Class (Ambler et al., 1991).

L. enzymogenes is a non-pathogenic soil bacterium that probably does not encounter high enough concentrations of $\beta$-lactams in nature to achieve a significant induction of lactamase production. Thus, the physiological role of the enzyme for this organism is not clear. However, we thought it was important to describe the enzyme in detail to compare it to other lactamases and trace its origin. Furthermore, a comparison of the $\beta$ lactamase gene with the genes of the $\alpha$-lytic protease (Epstein \& Wensink, 1987; Silen et al., 1989) and the 
secreted phosphatase (Au et al., 1991) of L. enzymogenes should allow us to gain more insight into the secretion and the targeting of extracellular enzymes by this organism.

In this paper we report the cloning and characteristics of the $L$. enzymogenes $\beta$-lactamase gene. Most of the primary amino acid sequence of the enzyme was deduced from the nucleotide sequence. It belongs to Class A and a comparison of the enzyme with other $\beta$-lactamases indicates that it has a unique primary structure. The cloned gene was expressed in Escherichia coli.

\section{Methods}

Bacterial strains and plasmids. Lysobacter enzymogenes ATCC 29487 was used for the preparation of genomic DNA and for the production of $\beta$-lactamase. Escherichia coli LE392 (Murray et al., 1977) was used to establish the recombinant $\lambda$ phage library and $E$. coli MV1193 (Vieira \& Messing, 1987) for the isolation of recombinant plasmids and the generation of single-stranded plasmid DNA. $\lambda$-DASH DNA (Sorge, 1988) was used to prepare the library of L. enzymogenes DNA, and pUC118 for subcloning restriction fragments and, together with phage M13K07, to generate single-stranded (ss) DNA (Vieira \& Messing, 1987). pUC118 was also used to express the $L$. enzymogenes $\beta$-lactamase gene in E. coli MV1193.

Reagents and enzymes. The sources of restriction endonucleases, T4 DNA ligase, polynucleotide kinase, the large fragment of $E$. coli DNA polymerase, T7 DNA polymerase, $\left[\alpha-{ }^{32} \mathrm{P}\right] \mathrm{dATP}$ and $\left[\gamma^{32} \mathrm{P}\right] \mathrm{ATP}$ and other reagents and chemicals have been reported previously (Au et al., 1991; von Tigerstrom \& Boras, 1990).

Culture conditions and $\beta$-lactamase assay. The maintenance of $L$. enzymogenes (von Tigerstrom \& Stelmaschuk, 1987) and the conditions used to grow the organism for the production of $\beta$-lactamase (von Tigerstrom \& Boras, 1990) have been described previously. Stock cultures of transformed $E$. coli cells were kept at $-70{ }^{\circ} \mathrm{C}$ in $0.8 \%(\mathrm{w} / \mathrm{v})$ tryptone, $0.5 \%(\mathrm{w} / \mathrm{v})$ yeast extract, $0.25 \%(\mathrm{w} / \mathrm{v}) \mathrm{NaCl}, 10 \%(\mathrm{w} / \mathrm{v})$ glycerol. Genomic DNA was prepared from cells grown in $3 \%$ (w/v) trypticase soy broth. Culture conditions for E. coli LE392 and MV1193 have been described previously (Au et al., 1991). For the production of $\beta$-lactamase by $E$. coli MV1193 transformed with pUC118 or with pGB-2a, the cells were grown aerobically at $37^{\circ} \mathrm{C}$ for $17 \mathrm{~h}$ in $2 \times \mathrm{YT}$ $[1.6 \%(\mathrm{w} / \mathrm{v})$ tryptone, $1.0 \%(\mathrm{w} / \mathrm{v})$ yeast extract, $0.5 \%(\mathrm{w} / \mathrm{v}) \mathrm{NaCl}]$ containing $100 \mu \mathrm{g}$ ampicillin $\mathrm{ml}^{-1}$ and $0.5 \mathrm{~mm}$-IPTG. The cells were suspended in $50 \mathrm{~mm}$-Tris $/ \mathrm{HCl}, \mathrm{pH} 7 \cdot 5$, disrupted in a French pressure cell and centrifuged at $3000 \mathrm{~g}$ for $15 \mathrm{~min}$ to prepare the cell-free extract. The $\beta$-lactamase assays were carried out at $22^{\circ} \mathrm{C}, \mathrm{pH} \mathrm{7.5}$, with 7 thienyl-2-acetamido)-3-[4- $N, N$-dimethyl-aminophenylazo)-pyridinium methyll-3-cephem-4-carboxylic acid (PADAC) as the substrate (von Tigerstrom \& Boras, 1990). The cell-free extract was diluted, usually 100 -fold, using $50 \mathrm{~mm}$-Tris $/ \mathrm{HCl}, 0.2 \mathrm{mg}$ bovine serum albumin $\mathrm{ml}^{-1}$, $\mathrm{pH} 7.5$. The effect of $p$ CMBS on $\beta$-lactamase activity was determined by incubating the diluted enzyme with and without $0.10 \mathrm{mM}-p \mathrm{CMBS}$ for $10 \mathrm{~min}$ at $22^{\circ} \mathrm{C}$ immediately before the assay. The $p$ CMBSsensitive activity was determined by subtracting the activity obtained in the presence of $p$ CMBS from the activity obtained without $p$ CMBS.

Oligonucleotide probes and primers. Oligonucleotide probes based on the $\mathrm{N}$-terminal amino acid sequence of the Lysobacter $\beta$-lactamase (von Tigerstrom \& Boras, 1990) and 17mer oligonucleotide primers for the sequencing reactions were synthesized in our department ( $\mathrm{Au}$ et al., 1991).
EcoRI fragments, obtained by digestion of pGB-2a and isolation by agarose gel electrophoresis were labelled by the random primer method (Feinberg \& Vogelstein, 1983, 1984) for use as hybridization probes of the restriction digests of $L$. enzymogenes DNA.

Recombinant methods. The procedures used for the isolation and sequencing of DNA and related methods were described by Sambrook et al. (1989) and Au et al. (1991). From the genomic library a BamHI fragment of about $12 \mathrm{~kb}$ was cloned into pUC118. It was called pGB-1 and was used to generate pGB-2a and pGB-2b, subclones of approximately $1 \mathrm{~kb} E c o$ RI fragments oriented in both directions in pUC118. A further subclone of a $S p h \mathrm{I}$ fragment of about $1.2 \mathrm{~kb}$ was called pGB-3.

Other methods. The adsorption of the Lysobacter $\beta$-lactamase to CMSephadex, its subsequent elution, and the electrophoresis of the native $\beta$-lactamase and activity staining with PADAC have been described previously (von Tigerstrom \& Boras, 1990). The $\beta$-lactamase produced by $E$. coli MV1193 (pGB-2a) was purified from cell-free extracts by the published method (von Tigerstrom \& Boras, 1990). In addition, SDSPAGE was used as a final purification step before the N-terminal amino acid sequence of the enzyme was obtained by the Tripartite Microanalytical Centre, University of Victoria, Victoria, BC, Canada. The osmotic shocking procedure was carried out according to the method of Neu \& Heppel (1965) at pH 8.0 and also at $\mathrm{pH} 11.0$, in which case the shock fluid was adjusted to $\mathrm{pH} 8.0$ immediately after centrifugation. The $\beta$-lactamase sequence homology searches were made using FASTA Serve Search Results (Pearson \& Lipman, 1988) from the GenBank Retrieval System. The amino acid sequence of the $L$. enzymogenes $\beta$-lactamase, deduced from the nucleotide sequence of its gene, was compared pair-wise to other $\beta$-lactamase sequences using the Lipman-Pearson Align program of DNASTAR.

\section{Results and Discussion}

\section{Isolation of the $\beta$-lactamase gene}

L. enzymogenes was grown and its DNA was isolated as described in Methods. The DNA was subjected to a partial digestion with endonuclease $M b o I$. DNA fragments of about $20 \mathrm{~kb}$ were isolated on a sucrose gradient and cloned into $\lambda$-DASH to obtain the genomic library for L. enzymogenes.

The N-terminal amino acid sequence of the $\beta$ lactamase has been reported previously (von Tigerstrom $\&$ Boras, 1990). The information was used to synthesize two oligonucleotide probes as shown in Table 1. Based on the information we had obtained from the secreted phosphatase of L. enzymogenes (Au et al., 1991), we used $\mathrm{G}$ or $\mathrm{C}$ nucleotides in the third position of nearly all codons. Probe 1, based on the codons for amino acids 3-13 was used to clone and sequence approximately $1 \mathrm{~kb}$ of a $2.1 \mathrm{~kb} S a l \mathrm{I}$ fragment. However, the nucleotide sequence obtained did not encode the expected amino acid sequence, nor was it related to any known $\beta$ lactamase gene. Further work was carried out using probe 2, based on the codons for amino acids 11-20. With this probe we isolated a clone called LEM-2 $(L$. enzymogenes, MboI, probe 2) from the genomic library. We selected a BamHI fragment of about $12 \mathrm{~kb}$ from a 
Table 1. $N$-Terminal amino acid sequence of $\beta$-lactamase from L. enzymogenes and constructed oligonucleotide probes

\begin{tabular}{cccc}
\hline \hline & & \multicolumn{2}{c}{ Codons } \\
\cline { 4 - 4 } Position & Amino acid & Probe 1 & Probe 2 \\
\hline 1 & Leu & & \\
2 & Ser & & \\
3 & Pro & CCG/C & \\
4 & Lys & AAG & \\
5 & Pro & CCG/C & \\
6 & Ala & GCG/C & \\
7 & Ala & GCG/C & \\
8 & Ser & TCG & \\
9 & Ala & GCG/C & \\
10 & Asp & GAC & GCG/C \\
11 & Ala & GCG/C & GCG/C \\
12 & Ala & GC & GCG/C \\
13 & Leu & & CTG/C \\
14 & Arg & & CGG/C \\
15 & Ala & & GCG/C \\
16 & Arg & & CGG/C \\
17 & Leu & & CTG/C \\
18 & Ala & & GCG/C \\
19 & Glu & & GAA/G \\
20 & Leu & & CT \\
\hline \hline
\end{tabular}

number of restriction digests of LEM-2 and cloned it into pUC118 to obtain pGB-1. This, in turn, was used to generate subclones in pUC1 18 with the $\beta$-lactamase gene in both directions (pGB-2a and pGB-2b), using approximately $1 \mathrm{~kb}$ EcoRI fragments and also to generate a subclone (pGB-3) using a $S p h$ I fragment of similar size. Fig. 1 shows restriction digests of $L$. enzymogenes DNA hybridized with a probe for the EcoRI fragment containing the $\beta$-lactamase gene of $L$. enzymogenes. The probe hybridized strongly to one $B a m \mathrm{HI}$ fragment of $12 \mathrm{~kb}$, to one $E c o$ RI fragment of about $1.0 \mathrm{~kb}$ and to two $S p h$ I fragments of similar size. The presence of two bands is in agreement with the fact that the $\beta$-lactamase gene has a $S p h I$ site, as indicated below.

\section{Sequencing of the lactamase gene}

ssDNA was generated from the cloned fragments and the DNA sequencing was carried out as described in Methods. The strands of the $\beta$-lactamase gene were sequenced using mainly pGB-2a and pGB- $2 b$ as indicated in Fig. 2. ssDNA generated from pGB-2a was used to sequence the coding strand (right to left) and ssDNA generated from $p G B-2 b$ was used to sequence the noncoding strand (left to right). Some of the unique restriction sites are indicated. A 1017 bp EcoRI fragment contained the whole $\beta$-lactamase gene. The $S p h$ I fragment (pGB-3), however, was lacking about $35 \%$ of the gene corresponding to the $\mathrm{C}$-terminal end of the enzyme.

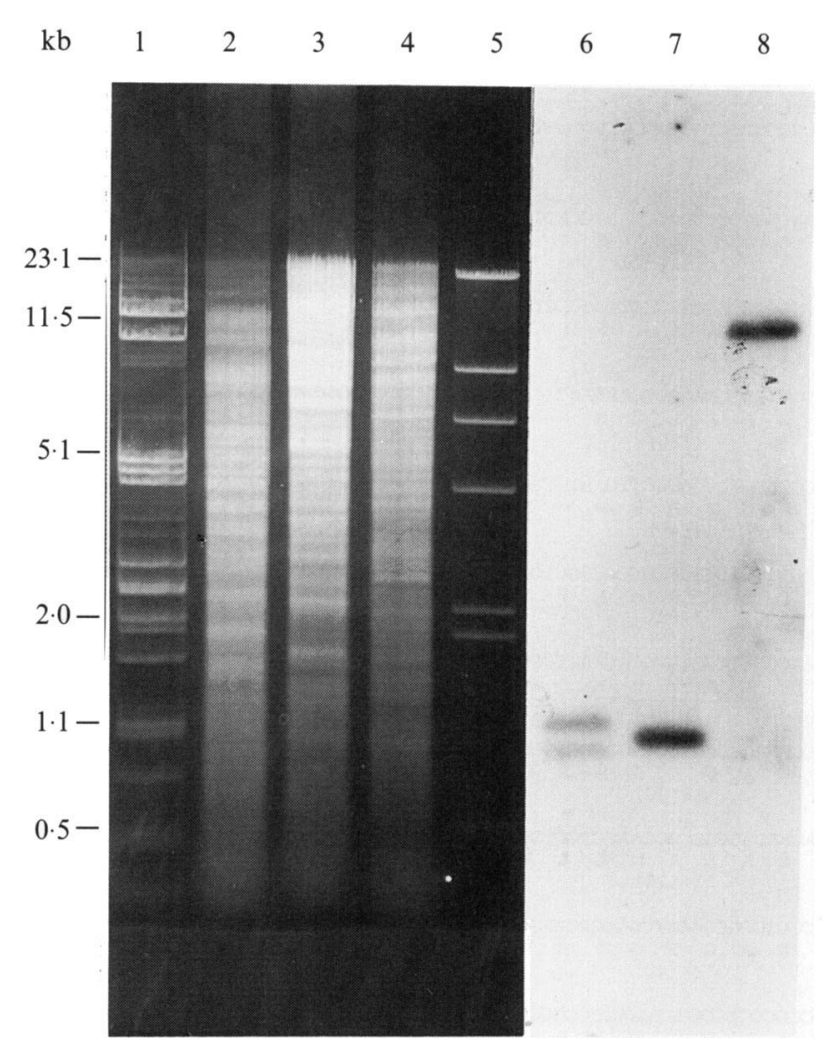

Fig. 1. Hybridization of the gene probe for $L$. enzymogenes $\beta$ lactamase. Lanes 1 to 5 are ethidium bromide-stained agarose gels of $\lambda$ DNA molecular mass standards digested with PstI (1) and HindIII (5) and L. enzymogenes genomic DNA digested with $S p h \mathrm{I}$ (2), EcoRI (3) and BamHI (4). Lanes 6, 7 and 8 are autoradiographs of Southern transfers of lanes 2,3 and 4, respectively, which were hybridized with ${ }^{32} \mathrm{P}$-labelled random primer probes.

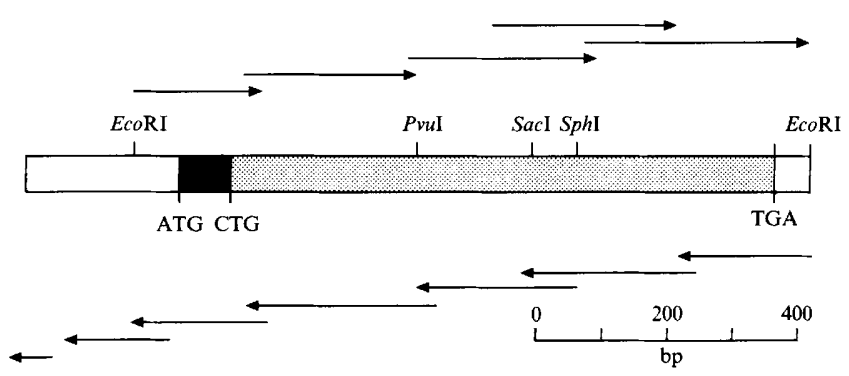

Fig. 2. Sequencing strategy of the $L$. enzymogenes $\beta$-lactamase gene. The arrows indicate the direct of sequencing. Some key restriction sites are indicated and ATG and CTG indicate the start of the signal sequence (black) and of the mature $\beta$-lactamase (stippled), respectively.

The nucleotide sequence of $1190 \mathrm{bp}$ containing the $\beta$-lactamase gene and the deduced amino acid sequence of the $\beta$-lactamase are shown in Fig. 3. The nucleotide sequence from 234 to 1143 encodes a 27 amino acid signal sequence and the mature $\beta$-lactamase of 276 amino acids. The calculated mass of the $\beta$-lactamase is 


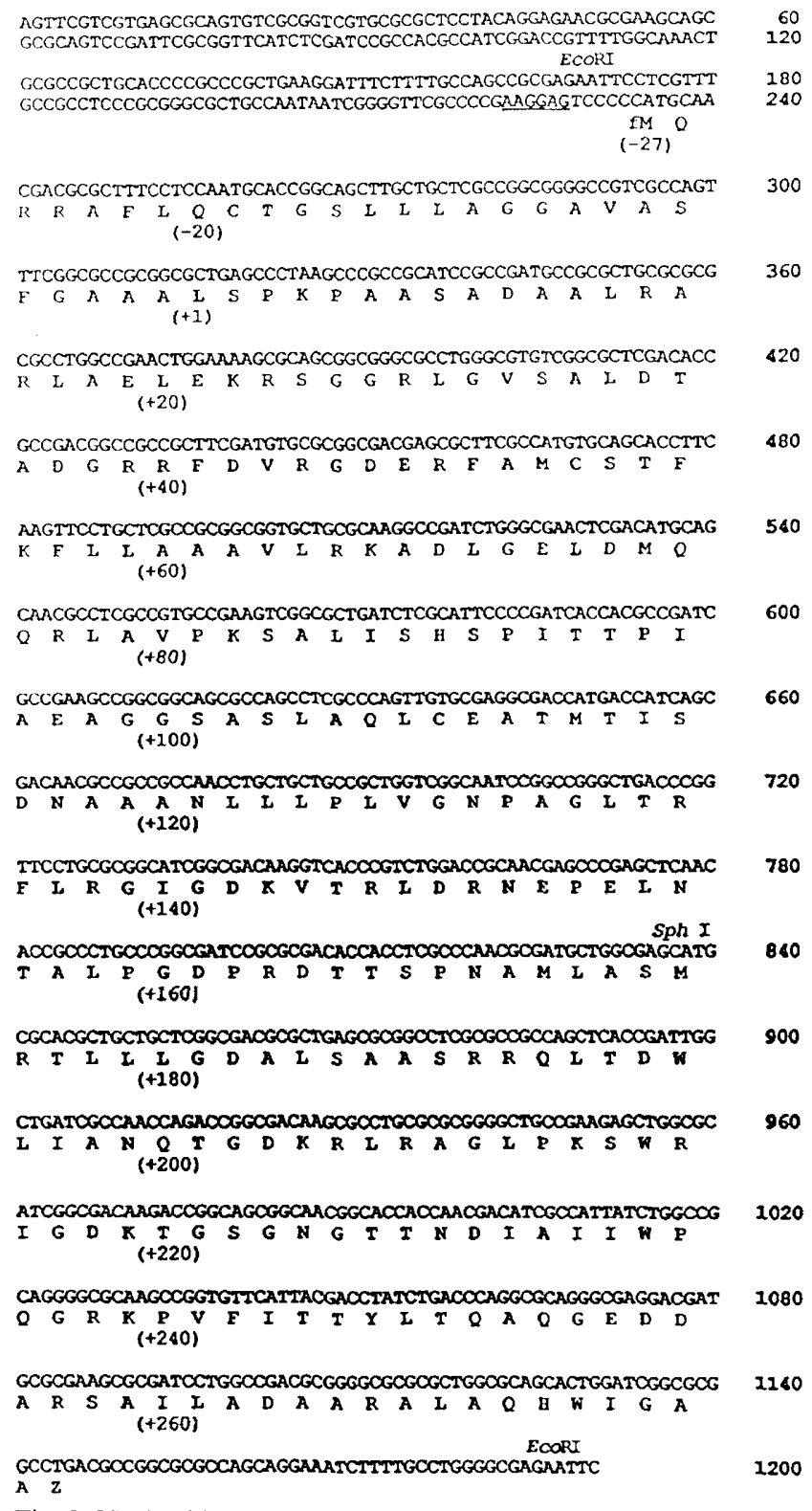

Fig. 3. Nucleotide sequence and deduced amino acid sequence of the $L$. enzymogenes $\beta$-lactamase. The two EcoRI sites are indicated. The probable ribosome binding site is underlined. Amino acid sequence -27 to -1 represents the signal sequence and amino acid +1 represents the $\mathrm{N}$ terminus of the mature $\beta$-lactamase.

$29146 \mathrm{Da}$, in good agreement with the value of $28 \mathrm{kDa}$ determined by SDS-PAGE (von Tigerstrom \& Boras, 1990). The deduced amino acid sequence of the $\mathrm{N}$ terminal end also agrees perfectly with the sequence obtained from the isolated enzyme. The $\mathrm{G}+\mathrm{C}$ content of the gene is $71.5 \%$, reflecting the high $\mathrm{G}+\mathrm{C}$ content of L. enzymogenes DNA (Christensen \& Cook, 1978). A possible ribosome binding site is located between nucleotides 222 and 228 . The two EcoRI restriction sites at positions 168 and 1185 , and the $S p h I$ site at nucleotide 840 are indicated in Fig. 3.

40


Table 2. Comparison of Lysobacter $\beta$-lactamase to other Class A $\beta$-lactamases

\begin{tabular}{|c|c|c|c|}
\hline Organism & $\begin{array}{l}\text { Similarity } \\
\text { index }\end{array}$ & $\begin{array}{l}\text { Cysteine in } \\
\text { active site }\end{array}$ & Reference \\
\hline Lysobacter enzymogenes & $100 \cdot 0$ & + & This study \\
\hline Citrobacter diversus & $48 \cdot 1$ & + & Perilli et al. (1991) \\
\hline Klebsiella oxytoca E23004 & $47 \cdot 7$ & + & Arakawa et al. (1989) \\
\hline Streptomyces albus & $46 \cdot 8$ & + & Dehottay et al. (1987) \\
\hline Yersinia enterocolitica & $46 \cdot 7$ & + & GenBank (X57079) \\
\hline Consensus $\beta$-lactamase & $45 \cdot 4$ & - & Ambler et al. (1991) \\
\hline Escherichia coli (PIT-2) & $41 \cdot 6$ & - & Barthelemy et al. (1988). \\
\hline Streptomyces fradiae & $41 \cdot 1$ & - & Forsman et al. (1990) \\
\hline Klebsiella sp. & $40 \cdot 9$ & - & Mercier \& Levesque (1990) \\
\hline Escherichia coli (TEM) & $40 \cdot 8$ & - & Sutcliffe $(1978)$ \\
\hline Klebsiella pneumoniae & $40 \cdot 6$ & - & Arakawa et al. (1986) \\
\hline Enterobacter cloacae & $40 \cdot 5$ & - & Shlaes et al. (1990) \\
\hline Streptomyces aureofaciens & $40 \cdot 4$ & + & GenBank (X13597) \\
\hline Streptomyces badius & $40 \cdot 2$ & - & Forsman et al. (1990) \\
\hline Rhodopseudomonas capsulata & $39 \cdot 0$ & - & Campbell et al. (1989) \\
\hline Streptomyces cacaeoi & $38 \cdot 3$ & - & Forsman et al. (1989) \\
\hline Bacillus cereus (PSE-4) & $37 \cdot 8$ & - & Sloma \& Gross (1983) \\
\hline Pseudomonas aeruginosa & $37 \cdot 7$ & - & Boissinot \& Levesque (1990) \\
\hline Bacillus cereus (III) & $37 \cdot 1$ & - & Hussain et al. (1987) \\
\hline Bacillus cereus 5/B & $36 \cdot 6$ & - & Wang et al. (1985) \\
\hline Bacillus licheniformis & $35 \cdot 8$ & - & Neugebauer et al. (1981) \\
\hline Streptomyces cacaeoi $\mathrm{Ulg}$ & $35 \cdot 6$ & - & Lenzini et al. (1988) \\
\hline Staphylococcus aureus & $28 \cdot 7$ & - & Chan (1986) \\
\hline Enterococcus faecalis & $28 \cdot 1$ & - & GenBank (M60253) \\
\hline
\end{tabular}

of Citrobacter diversus (Perilli et al., 1991) and Klebsiella oxytoca E 23004 (Arakawa et al., 1989). However, in contrast to the high $\mathrm{G}+\mathrm{C}$ content of the gene for the Lysobacter $\beta$-lactamase, the genes of the enzymes from these organisms have a $\mathrm{G}+\mathrm{C}$ content of only $54 \%$ (Perilli et al., 1991) and 58\% (Arakawa et al., 1989), respectively. Recently Ambler et al. (1991) analysed 20 Class A $\beta$-lactamases and proposed a consensus sequence to allow for easier comparison. In Fig. 4 the sequence of the mature Lysobacter $\beta$-lactamase is compared to this consensus sequence and to the $C$. diversus $\beta$-lactamase. The numbering of the sequences is according to that proposed for the consensus sequence (Ambler et al., 1991). Thus, the N- and C-termini of the Lysobacter enzyme are Leu (ABL 17) and Ala (ABL 294), respectively. Compared to the consensus sequence there are two single amino acid deletions (ABL 60 and 253), one two-amino acid deletion (ABL 239 and 240) and a two-amino acid insertion (Pro and Ile) after ABL 110. We feel that this insertion does not warrant a change in the numbering of the consensus sequence at this time. A revision of the consensus sequence might be necessary in the future if more insertions are found in other $\beta$ lactamases. In the consensus sequence there are 22 conserved amino acids (underlined in Fig. 4). All but one (ABL 184) of these positions are also conserved in the Lysobacter $\beta$-lactamase. The proposed active site of the Class A $\beta$-lactamases around the serine at ABL 70, with the three conserved amino acids, is overlined in Fig. 4.
The lactamase of L. enzymogenes has a cysteine at $\mathrm{ABL}$ 69 , in agreement with the inhibition of the enzyme by $p \mathrm{CMB}$ and $p \mathrm{CMBS}$ reported previously (von Tigerstrom \& Boras, 1990).

A further comparison of the Lysobacter enzyme to other Class A $\beta$-lactamases and the consensus $\beta$ lactamase was made as described in Methods. Table 2 lists the similarity indices that we obtained. The indices are approximately equal to the percentage of identical amino acids in the sequence and range from 28.1 to $48.1 \%$ for the enzymes from Enterococcus faecalis and $C$. diversus, respectively, with a similarity index of 45.4 for the consensus $\beta$-lactamase.

\section{Expression of the $\beta$-lactamase gene}

The cloned $E c o$ RI fragment in pUC118, described above as pGB-2a, was used for the expression of the $\beta$ lactamase gene in $E$. coli since the $\beta$-lactamase gene was inserted in the correct orientation behind the lac promotor. E. coli MV1193 was transformed with pGB2a. The isolates were grown as described in Methods and cell-free extracts were prepared from their cultures for the determination of $\beta$-lactamase activities. The $\beta$-lactamase of $L$. enzymogenes is inhibited by $p$ CMBS (von Tigerstrom \& Boras, 1990), whereas the TEM $\beta$ lactamase encoded by pUC118 is not (Bush, 1989). We confirmed this in our study. Thus, assays with and without $p$ CMBS served as a means to detect Lysobacter 
Table 3. Production of Lysobacter $\beta$-lactamase Values given are from a representative experiment. Values in brackets indicate $\mu \mathrm{mol} \mathrm{min}^{-1}$ $\left(\mathrm{OD}_{600} \text { unit }\right)^{-1}$.

\begin{tabular}{lllc}
\hline \hline & \multicolumn{3}{c}{$\beta$-Lactamase activity $\left[\mu \mathrm{mol} \mathrm{min}^{-1}(\mathrm{ml} \text { culture })^{-1}\right]$} \\
\cline { 2 - 4 } Organism and plasmid & \multicolumn{1}{c}{ - $\mathrm{CMBS}$} & $+p$ CMBS & $p$ CMBS-sensitive \\
\hline L. enzymogenes & $0.29(0.049)$ & $0.03(0.0049)$ & $0.26(0.044)$ \\
E. coli MV1193 (pUC118)* & $0.17(0.020)$ & $0.17(0.020)$ & 0.00 \\
E. coli MV1193 (pGB-2a)* & $1.99(0.29)$ & $0.28(0.041)$ & $1.71(0.25)$ \\
\hline \hline
\end{tabular}

* Values from the early stationary phase of growth are used.

$\beta$-lactamase activity. Four of 16 isolates seemed to produce significant amounts of the Lysobacter enzyme. One was selected for a more detailed analysis. Table 3 shows the $\beta$-lactamase activities in a representative experiment in the presence and absence of $p$ CMBS in cell-free extracts of $L$. enzymogenes and of $E$. coli MV1193, transformed with pUC118 or pGB-2a. The activity is highest from pGB-2a and, more significantly, it is inhibited by $p$ CMBS nearly as much as the $\beta$ lactamase from $L$. enzymogenes. The enzyme activity from pGB-2a also was adsorbed to CM-Sephadex at $\mathrm{pH} 7 \cdot 5$, whereas the lactamase encoded by $\mathrm{pUC} 118$ was not. This is in agreement with the different isoelectric points of about $9 \cdot 6$ for the $L$. enzymogenes $\beta$-lactamase (von Tigerstrom \& Boras, 1990) and 5.4 for the TEM $\beta$-lactamase (Bush, 1989). Furthermore, the $\beta$-lactamase activity from pGB-2a was increased by a factor of six in the presence of IPTG, in agreement with the position of the lactamase gene in pUC118.

Determining $\beta$-lactamase activities during the growth of $E$. coli MV1193 (pGB-2a), we found that Lysobacter $\beta$-lactamase was produced mainly after the exponential growth phase. Mean values \pm SD were calculated from six determinations. Stationary phase cultures had $\beta$ lactamase activities of $2 \cdot 2 \pm 1 \cdot 3 \mu \mathrm{mol} \mathrm{min}{ }^{-1} \mathrm{ml}^{-1}$, of which $1.6 \pm 0.35 \mu \mathrm{mol} \mathrm{min}{ }^{-1} \mathrm{ml}^{-1}$ or $71 \pm 16 \%$ was $p$ CMBSsensitive. In exponentially growing cells only $11.3 \pm 7 \%$ of the activity was $p$ CMBS-sensitive. Thus cultures in the early stationary phase were used for the characterization of the expressed Lysobacter $\beta$-lactamase.

In a separate experiment we attempted to determine the location of the Lysobacter $\beta$-lactamase in E. coli MV1193 (i.e. the $p$ CMBS-sensitive activity). A culture grown to just past the exponential growth phase $\left(\mathrm{OD}_{600}=5.4\right.$ and $60 \%$ inhibition of $\beta$-lactamase with $p$ CMBS) was used to prepare shock fluids and shocked cells at $\mathrm{pH} 8$ and $\mathrm{pH} 11$. Essentially all of the $p$ CMBSresistant $\beta$-lactamase was released into the shock fluid at both $\mathrm{pH}$ values. Little or no $p$ CMBS-sensitive activity was released from the cells at $\mathrm{pH} 8$ but $32 \%$ of the $\beta$-lactamase was released at $\mathrm{pH} 11$. We believe that both enzymes are located in the periplasm but that the Lysobacter $\beta$-lactamase, due to its high isoelectric point, is held more tightly in the periplasm by ionic interaction with negatively-charged cell envelope components than the TEM $\beta$-lactamase. We also observed that $E$. coli MV1193 transformed with pGB-2a always releases some $p$ CMBS-resistant $\beta$-lactamase but no $p$ CMBS-sensitive $\beta$-lactamase into the culture medium.

\section{$P A G E$ and $N$-terminal sequencing}

PAGE at low $\mathrm{pH}$ was carried out using the following enzyme preparations: (i) $\beta$-lactamase from the concentrated shock fluid of L. enzymogenes (von Tigerstrom \& Boras, 1990); (ii) $p$ CMBS-sensitive $\beta$-lactamase from $E$. coli MV1193 transformed with pGB-2a, partially purified from cell-free extract by CM-Sephadex chromatography; (iii) partially purified TEM $\beta$-lactamase from $E$. coli MV1193 transformed with pUC118. The electrophoretic mobilities relative to methyl green were $0.58,0.58$ and $0 \cdot 52$, respectively. In addition, the $\beta$-lactamase expressed from pGB-2a was purified as described in Methods to determine the N-terminal amino acid sequence of the protein. A sequence of 19 residues was obtained and all but residue 16 (asp) agreed with the $\mathrm{N}$-terminal sequence of the mature $\beta$-lactamase (von Tigerstrom \& Boras, 1990) and with the sequence shown in Fig. 3, which has only a $10 \%$ identity with the $\mathrm{N}$-terminal sequence of the TEM $\beta$-lactamase.

\section{Concluding remarks}

The gene of the $\beta$-lactamase of $L$. enzymogenes was isolated and the DNA sequence was determined. This appears to be the first characterization of a $\beta$-lactamase gene from a gliding bacterium. The gene was found to contain $909 \mathrm{bp}$, with a $\mathrm{G}+\mathrm{C}$ content of $71.5 \%$, located in a $1017 \mathrm{bp} E c o$ RI fragment of the genomic DNA. The gene encodes the pre- $\beta$-lactamase comprising the signal sequence of 27 amino acids and the mature enzyme of 276 amino acids. Comparing the amino acid sequences 
of the Lysobacter $\beta$-lactamase to the sequence of the Class A consensus $\beta$-lactamase (Ambler et al., 1991), a similarity index of 45.4 was obtained. Thus, the enzyme is a typical Class A $\beta$-lactamase. Based on the similarity indices, the enzyme is most closely related to the $\beta$ lactamases of $C$. diversus, $K$. oxytoca, $S$. albus and $Y$. enterocolitica (similarity indices of 48.1 to 46.7 ). The Lysobacter enzyme also shares the presence of a cysteine at ABL 69 with the $\beta$-lactamases of these four organisms and the $\beta$-lactamase of $S$. aureofaciens (similarity index of 40.4$)$. We believe that this cysteine residue in the Lysobacter $\beta$-lactamase is the site of $p$ CMBS inhibition.

The origin of the $\beta$-lactamase of $L$. enzymogenes is not clear. Since $L$. enzymogenes is a typical soil organism, the enzyme probably has not arisen from the over-use of $\beta$ lactam antibiotics during the last 50 years. Compared to other Class A $\beta$-lactamases, the Lysobacter enzyme is unique in that it has two additional amino acids after ABL 110 and a two amino acid deletion at ABL 239 and 240 . This and the similarity of the $\mathrm{G}+\mathrm{C}$ content of the $\beta$-lactamase gene $(71.5 \%)$ to the $\mathrm{G}+\mathrm{C}$ content of the $L$. enzymogenes genomic DNA (69\%) (Christensen \& Cook, 1978) may indicate that the enzyme has evolved for some time in L. enzymogenes. Alternatively, it may have been acquired recently from another soil organism with a high $\mathrm{G}+\mathrm{C}$ content, such as a Streptomyces or $P$ seudomonas species. It is unlikely that $\beta$-lactamase was acquired from organisms such as $C$. diversus and $K$. oxytoca, since the genes of their $\beta$-lactamases have a much lower $\mathrm{G}+\mathrm{C}$ content.

The plasmid pGB-2a was used for the sequencing and the expression of the Lysobacter $\beta$-lactamase gene in $E$. coli. Since this plasmid also encodes the TEM $\beta$ lactamase of pUC118, we had to show specifically that the $\beta$-lactamase genes of $L$. enzymogenes was expressed. This was possible by selective inhibition of the Lysobacter enzyme with $p C M B S$, selective adsorption to CMSephadex, separation of the TEM and Lysobacter $\beta$-lactamases by PAGE, and determination of the $\mathrm{N}$-terminal amino acid sequence of the enzyme produced by the cloned gene. The results clearly show that the $\beta$-lactamase of $L$. enzymogenes was expressed by $E$. coli and that the enzyme was processed to yield the mature $\beta$-lactamase.

We thank Patricia Murray for the preparation of the oligonucleotides. This work was supported by the Natural Sciences and Engineering Research Council of Canada.

\section{References}

Ambler, R. P. (1980). The structure of $\beta$-lactamases. Philosophical Transactions of the Royal Society B289, 321-331.

Ambler, R. P., Coulson, A. F. W., Frere, J.-M., Ghuysen, J.-M., Joris, B., Forsman, M., Levesque, R. C., Tiraby, G. \& Waley,
S. G. (1991). A standard numbering scheme for the class A $\beta$-lactamases. Biochemical Journal 276, 269-272.

arakawa, Y., Ohta, M., Kido, N., Fujil, Y., Komatsu, T. \& Kato, N. (1986). Close evolutionary relationship between the chromosomally encoded $\beta$-lactamase gene of Klebsiella pneumonia and the TEM $\beta$-lactamase gene mediated by R-plasmids. FEBS Letters 207 , 69-74.

Arakawa, Y., Ohta, Kido N., Mori, M., Ito, H., Komatsu, T., Fuji, Y. \& KaTo, N. (1989). Chromosomal $\beta$-lactamase of Klebsiella oxytoca, a new Class A enzyme that hydrolyses broad-spectrum $\beta$ lactam antibiotics. Antimicrobial Agents and Chemotherapy 33, 63-70.

Au, S., Roy, K. L. \& von Tigerstrom, R. G. (1991). Nucleotide sequence and characterization of the gene for secreted alkaline phosphatase from Lysobacter enzymogenes. Journal of Bacteriology 173, 4551-4557.

Barthelemy, M., Reduzzi, J. \& Labia, R. (1988). Complete amino acid sequence of p453-plasmid-mediated PIT-2 $\beta$-lactamase. Biochemical Journal 251, 73-79.

Boissinot, M. \& Levesque, R. C. (1990). Nucleotide sequence of the PSE-4 carbenicillinase gene and correlations with the Staphylococcus aureus PCI $\beta$-lactamase crystal structure. Journal of Biological Chemistry 265, 1225-1230.

BusH, K. (1989). Classification of $\beta$-lactamases: groups 1, 2a, $2 \mathrm{~b}$ and $2 b^{\prime}$. Antimicrobial Agents and Chemotherapy 33, 264-270.

Campbell, J. I. A., Scahill, S., Gibson, T. \& Ambler, R. P. (1989). The phototrophic bacterium Rhodopseudomonas capsulata sp108 ecodes an indigenous class A $\beta$-lactamase. Biochemical Journal 260, 803-812.

ChAN, P. T. (1986). Nucleotide sequence of the Staphylococcus aureus PCI $\beta$-lactamase gene. Nucleic Acids Research 14, 5940.

Christensen, P. \& CoOK, F. D. (1978). Lysobacter, a new genus of non-fruiting gliding bacteria with a high base ratio. International Journal of Systematic Bacteriology 28 367-393.

Dehottay, P., Dusart, J., De Meester, F., Joris, B., Van Beeumen, J., Erpicum, T. \& Ghuysen, J.-M. (1987). Nucleotide sequence of the Streptomyces albus $\mathrm{G} \beta$-lactamase precursor. European Journal of Biochemistry 166, 345-350.

EPsteIn, D. M. \& Wensink, P. C. (1987). The $\alpha$-lytic protease gene of Lysobacter enzymogenes. Journal of Biological Chemistry 263, $16586-16590$.

Feinberg, J. \& Vogelstein, B. (1983). A technique for radiolabelling restriction endonuclease fragments to high specific activity. Analytical Biochemistry 132, 6-13.

FeINBERG, J. \& Vogelstein, B. (1984). A technique for radiolabelling restriction endonuclease fragments to high specific activity. Addendum. Analytical Biochemistry 137, 266-267.

Forsman, M., Lindgren, L., Haggstrom, B. \& Jaurin, B (1989). Transcriptional induction of Streptomyces cacaoi $\beta$-lactamase by $\beta$-lactam compounds. Molecular Microbiology 3, 1425-1432.

Forsman, M., Haggstrom, B., Lindgren, L. \& Jaurin, B. (1990). Molecular analysis of $\beta$-lactamases from four species of Streptomyces: comparison of amino acid sequences with those of other $\beta$-lactamases. Journal of General Microbiology 130, 589-598.

Huletsky, A., Couture, F. \& Levesque, R. C. (1990). Nucleotide sequence and phylogeny of SHV-2 $\beta$-lactamase. Antimicrobial Agents and Chemotherapy 34, 1725-1732.

Hussain, M., Pastor, F. I. J. \& Lampen, J. O. (1987). Cloning and sequencing of blaZ gene encoding $\beta$-lactamase III, a lipoprotein of Bacillus cereus $569 / \mathrm{H}$. Journal of Bacteriology 169, 579-586.

KirbY, R. (1992). Evolutionary origin of the class A and C $\beta$ lactamases. Journal of Molecular Evolution 34, 345-350.

Lenzini, M. V., Ishihara, H., Dusart, J., Ogawara, H., van Beeumen, J., Frere, J.-M. \& Ghuysen, J.-M. (1988). Nucleotide sequence of the gene encoding the active site serine $\beta$-lactamase from Streptomyces cacaoi. FEMS Microbiological Letters 49, 371-176.

Mercier, J. \& LeVesque, R. C. (1990). Cloning of SHV-2, OHIO-1, and OXA- $6 \beta$-lactamases and cloning and sequencing of SHV-1 $\beta$ lactamase. Antimicrobial Agents and Chemotherapy 34, 1577-1583.

Murray, N. E., Brammar, W. J. \& Murray, K. (1977). Lambdoid phages that simplify recovery of in vitro recombinants. Molecular and General Genetics 150, 53-61. 
Neu, H. L. \& HePpel, L. A. (1965). The release of enzymes from Escherichia coli by osmotic shock and during formation of sphaeroplasts. Journal of Biological Chemistry 246, 3685-3692.

Neugebauer, K., Sprengel, R. \& Schaller, H. (1981). Penicillinase from Bacillus licheniformis: nucleotide sequence of the gene and implications for the biosynthesis of a secretory protein in a Grampositive bacterium. Nucleic Acids Research 9, 2577-2588.

Pastor, N., Pinero, D., Valdes, A. M. \& Soberon, X. (1990). Molecular evolution of class A $\beta$-lactamases: phylogeny and patterns of sequence conservation. Molecular Microbiology 4, 1957-1965.

Pearson, W. R. \& LiPMAN, D. J. (1988). Improved tools for biological sequence comparisons. Proceedings of the National Academy of Sciences of the United States of America 85, 2444-2448.

Perilli, M., Duez, C., Joris, B. \& Frere, J.-M. (1991). Cloning and nucleotide sequencing of the gene encoding the $\beta$-lactamase from Citrobacter diversus. FEMS Microbiology Letters 83, 79-84.

SambrooK, J., Fritsch, E. F. \& Maniatis, T. (1989). Molecular Cloning: A Laboratory Manual, 2nd edn. Cold Spring Harbor, NY: Cold Spring Harbor Laboratory Press.

Shlaes, D. M., Currie-McCumber, C., Hull, A., Behlau, I. \& Kron, M. (1990). OHIO-1 $\beta$-lactamase is part of the SHV-I family. Antimicrobial Agents and Chemotherapy 34, 1570-1576.

Silen, J. L., Frank, D., Fujishige, A., Bone, R. \& Agard, D. A. (1989). Analysis of prepro- $\alpha$-lytic protease expression in Escherichia coli reveals that the proregion is required for activity. Journal of Bacteriology 171, 1320-1325.

Sloma, A. \& Gross, M. (1983). Molecular cloning and nucleotide sequence of the type I $\beta$-lactamase gene from Bacillus cereus. Nucleic Acids Research 11, 4997-5004.

SORGE, J. A. (1988). Bacteriophage lambda cloning vectors. In Vectors: A Survey of Molecular Cloning Vectors and Their Uses, p. 43. Edited by R. L. Rodriguez \& D. T. Denhardt. Stoneham, MA: Butterworth Publishers.

SutClifFe, J. G. (1978). Nucleotide sequence of the ampicillin resistance gene of Escherichia coli plasmid pBR322. Proceedings of the National Academy of Sciences of the United State of America 73, 3737-3741.

von Tigerstrom, R. G. \& Stelmaschuk, S. (1987). Purification and partial characterization of an amylase from Lysobacter brunescens. Journal of general Microbiology 133, 3437-3443.

von Tigerstrom, R. G. \& Boras, G. J. (1990). $\beta$-Lactamase of Lysobacter enzymogenes: induction, purification and characterization. Journal of General Microbiology 136, 521-527.

VieIRA, J. \& Messing, J. (1987). Production of single-stranded plasmid DNA. Methods in Enzymology 153, 3-11.

Wang, W., MezeS, P. S. F., Yang, Y. Q., Blocher, R. W. \& LAMPEN, J. O. (1985). Cloning and sequencing of the $\beta$-lactamase I gene of Bacillus cereus $5 / B$ and its expression in Bacillus subtilis. Journal of Bacteriology 163, 487-492. 